\title{
Biocontrol Mechanisms of Efficient Azotobacter Isolates against Fusarium solani Causing Fusarium wilt of Chilli (Capsicum annum L.) under in vitro Conditions
}

\author{
Swapna $^{1 *}$, K. Tamil Vendan ${ }^{1}$, Mahadevaswamy ${ }^{1}$, D.S. Aswathanarayana ${ }^{2}$ and \\ R.C. Gundappagol ${ }^{1}$
}

${ }^{1}$ Department of Agricultural Microbiology, ${ }^{2}$ Department of Plant Pathology, College of Agriculture, University of Agricultural Sciences, Raichur - 584104, Karnataka, India

*Corresponding author

\begin{tabular}{|c|c|}
\hline & B S T R A C T \\
\hline Keywords & \multirow{4}{*}{$\begin{array}{l}\text { In the present investigation, four efficient Azotobacter isolates were screened for various } \\
\text { biocontrol traits and evaluated for its biological deterrent activity against Fusarium solani. } \\
\text { Maximum per cent inhibition of } 60.25 \text { was observed in AZT-R } \mathrm{R}_{7} \text { isolate followed by AZT- } \\
\mathrm{Y}_{2}(59.17 \%) \text {, AZT- } \mathrm{J}_{1}(57.77 \%) \text { and AZT-G } \mathrm{G}_{4}(51.47 \%) \text {. AZT- } \mathrm{R}_{7} \text { recorded a maximum } \\
\text { siderophore, IAA production and highest } \mathrm{N}_{2} \text { fixation of } 82.83 \text { per cent, } 100.75 \mu \mathrm{g} 50 \mathrm{ml}^{-1} \\
\text { and } 10.33 \mathrm{mg} \mathrm{g}^{-1} \text {, respectively. All the four isolates showed positive for the HCN test and } \\
\text { the two isolates AZT- } \mathrm{R}_{7} \text { and AZT- } \mathrm{G}_{4} \text { showed positive for the } \mathrm{H}_{2} \mathrm{~S} \text { test and AZT-G } \mathrm{G}_{4} \text { for } \\
\text { Phosphorus solubilization. Therefore, Azotobacter isolate AZT- } \mathrm{R}_{7} \text { can be recommended } \\
\text { for commercial production as a potential biocontrol agent and an alternative to } P \text {. } \\
\text { fluorescens against Fusarium wilt in chilli grown in Hyderabad Karnataka region. }\end{array}$} \\
\hline & \\
\hline Article Info & \\
\hline $\begin{array}{l}\text { Accepted: } \\
\text { 18 August } 2018 \\
\text { Available Online: } \\
\text { 10 September } 2018\end{array}$ & \\
\hline
\end{tabular}

\section{Introduction}

Chilli (Capsicum annum L.) is an important vegetable crop and its socio-cultural role is remarkable worldwide. The enormous popularity and demand for chilli is providing a boost to the chilli industry, but its production is increasingly constrained by soil borne diseases. Fusarium wilt is the most important soil borne disease caused by Fusarium sp. To overcome this, several strategies have been devised, one such a strategy is the use of fungicides. Fungicides being chemical in nature cause havoc in the environment. As an alternative strategy, eco-friendly biological agent such as Pseudomonas fluorescens, Bacillus sp., and Trichoderma sp., has been developed to counteract wilt disease.

Use of complex cyst forming Azotobacter isolates with high rhizosphere competency will overcome the limitations in commercial production of existing commercial biocontrol agents. The present study aims at the selection of an efficient Azotobacter isolate with multiple biocontrol traits and development of 
Azotobacter inoculants with commercialization potential, a major challenge hindering the bioinoculant production technology. Such an isolate would be an alternative biocontrol agent to $P$. fluorescens for the management of Fusarium wilt of chilli grown in Hyderabad Karnataka region.

\section{Materials and Methods}

Isolation of Azotobacter isolates and Fusarium solani

Azotobacter isolates were isolated by using serial plate dilution technique (Wu et al., 2006). F. solani was isolated by tissue segment method (Rangaswamy and Mahadevan, 1999) on Potato Dextrose Agar medium (PDA).

Azotobacter isolates were tested for their inhibitory activity against mycelial growth of $F$. solani by following the dual culture technique (Dennis and Webster, 1971).

Elucidation of biocontrol mechanisms of efficient Azotobacter isolates against $F$. solani

The efficient Azotobacter isolates were further used in elucidating the mechanisms of biocontrol, such as siderophore production, hydrogen cyanide production, IAA production, in vitro $\mathrm{N}_{2}$ fixation and $\mathrm{H}_{2} \mathrm{~S}$ production test. $\mathrm{N}_{2}$ fixation by the isolates was estimated by the method described by Humpries (1956). All the isolates were screened for the production of $\mathrm{HCN}$ by adapting the method of Lorck (1948). In order to screen the production of siderophores, the Azotobacter isolates were grown in CAS agar medium. The inoculated agar plates were incubated at $37{ }^{\circ} \mathrm{C}$ for $24 \mathrm{~h}$. The observation was made for the change of medium color from blue to reddish yellow to determine the siderophores production. IAA production potential of Azotobacter isolates were tested in Ashby's nitrogen free broth supplemented with $0.005 \mathrm{M}$ concentration tryptophan at 28 ${ }^{0} \mathrm{C}$. The concentration of IAA in the culture broth after 3 days of incubation was centrifuged at 5,000 rpm for $5 \mathrm{~min}$ and determined by spectrophotometric method using Salkowaski's reagent (Mali et al., 2011). Phosphorus solubilization ability of Azotobacter isolates were studied on Pikovskaya's agar plates. The pure culture of Azotobacter isolate was spread on agar plates containing Pikovskaya's medium supplemented with phosphate and these plates were incubated at $25{ }^{0} \mathrm{C}$ for 4-5 days. Formation of halo zone was taken as positive for the solubilization of P. Sterilized SIM agar tubes were stab inoculated with the Azotobacter cultures and incubated for $48 \mathrm{~h}$ at $30{ }^{0} \mathrm{C}$. After incubation, the tubes with cultures observed for the development of black color along the line of the stab.

\section{Results and Discussion}

\section{Isolation of Azotobacter isolates $F$. solani}

After 4-6 days of incubation at $30^{\circ} \mathrm{C}$, the isolates formed small water droplets like white glistening colonies on Waksman No. 77 agar plates, later turned to brown to black colored colonies (Gibbs and Shapton, 1968).

The chilli plants showing typical wilted symptoms were used for the isolation of $F$. solani. The culture was developed on PDA medium in the Petri plates and observed the presence of fungal spores under the microscope. It was identified as $F$. solani based on the mycelial and conidial (microconidia, macroconidia and chlamydospores) characteristics through standard mycelial keys; the results are in agreement with the findings of Barnett and Hunter (1972) (Plate 1 and 2). 
Table.1 Per cent inhibition of mycelial growth of $F$. solani by efficient isolates of Azotobacter

\begin{tabular}{|c|c|c|}
\hline SI. No. & Azotobacter isolate & Per cent inhibition \\
\hline 1 & Control & 0.00 \\
\hline 2 & AZT-Y $_{2}$ & $59.17(50.28)^{\mathrm{a}}$ \\
\hline 3 & AZT-R $_{7}$ & $60.25(50.91)^{\mathrm{a}}$ \\
\hline 4 & AZT-J $_{1}$ & $57.77(49.47)^{\mathrm{b}}$ \\
\hline 5 & AZT-G $_{4}$ & $51.47(45.54)^{\mathrm{d}}$ \\
\hline 6 & Ref. Azotobacter & $53.43(46.97)^{\mathrm{c}}$ \\
\hline & SEm \pm & 0.14 \\
\hline & CD $(1 \%)$ & 0.58 \\
\hline
\end{tabular}

Note: Figures in the parentheses are arc sine transformed values

Table.2 Elucidation of biocontrol mechanisms of efficient Azotobacter isolates against $F$. solani

\begin{tabular}{|c|c|c|c|c|}
\hline SI. No. & Azotobacter isolate & $\begin{array}{l}\text { *Siderophore } \\
\text { production (\%) }\end{array}$ & $\begin{array}{l}\text { In vitro } \mathrm{N}_{2} \text { fixation (mg } \\
\mathrm{N}_{2} \text { fixed } \mathrm{g}^{-1} \text { of mannitol) }\end{array}$ & $\mathrm{IAA}\left(\mu \mathrm{g} 50 \mathrm{ml}^{-1}\right)$ \\
\hline 1 & Control & $1.99(8.11)^{\mathrm{c}}$ & 0.00 & 0.00 \\
\hline 2 & AZT-Y ${ }_{2}$ & $81.51(64.54)^{\mathrm{a}}$ & $9.13^{b}$ & $93.37^{b}$ \\
\hline 3 & AZT-R 7 & $82.83(65.54)^{\mathrm{a}}$ & $10.33^{\mathrm{a}}$ & $100.75^{\mathrm{a}}$ \\
\hline 4 & AZT-J ${ }_{1}$ & $79.98(63.44)^{\mathrm{ab}}$ & $9.02^{\mathrm{b}}$ & $81.00^{\mathrm{cd}}$ \\
\hline 5 & AZT-G 4 & $77.44(61.65)^{b}$ & $8.27^{\mathrm{c}}$ & $60.87^{\mathrm{e}}$ \\
\hline 6 & Ref. Azotobacter & $79.73(63.24)^{\mathrm{ab}}$ & $8.56^{\mathrm{bc}}$ & $82.00^{c}$ \\
\hline & SEm \pm & 0.52 & 0.06 & 0.40 \\
\hline & CD (1\%) & 1.62 & 0.27 & 1.63 \\
\hline
\end{tabular}

* Figures in parenthesis are arc sine transformed values

Plate.1 Growth of Azotobacter isolate on Waksman No. 77 plate

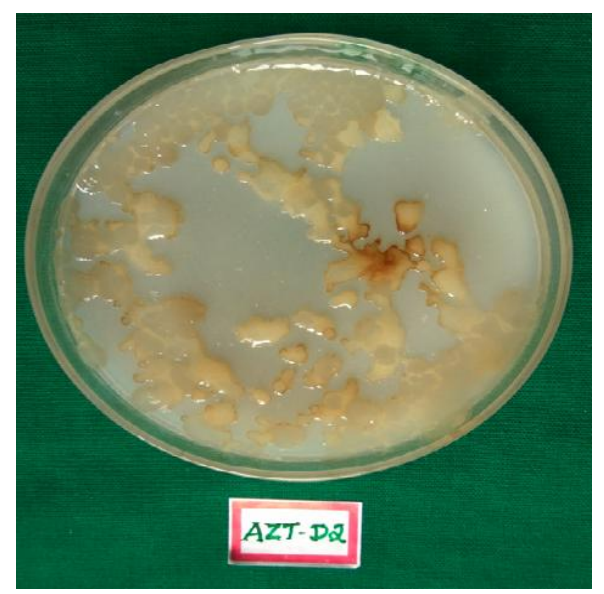


Plate.2 Growth of Fusarium solani on PDA plate

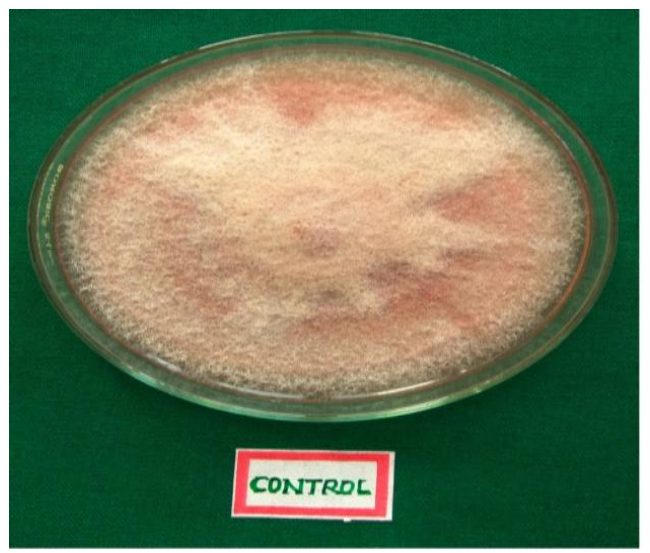

Plate.3 Inhibition of mycelial growth of $F$. solani by the efficient Azotobacter isolates after five days of incubation

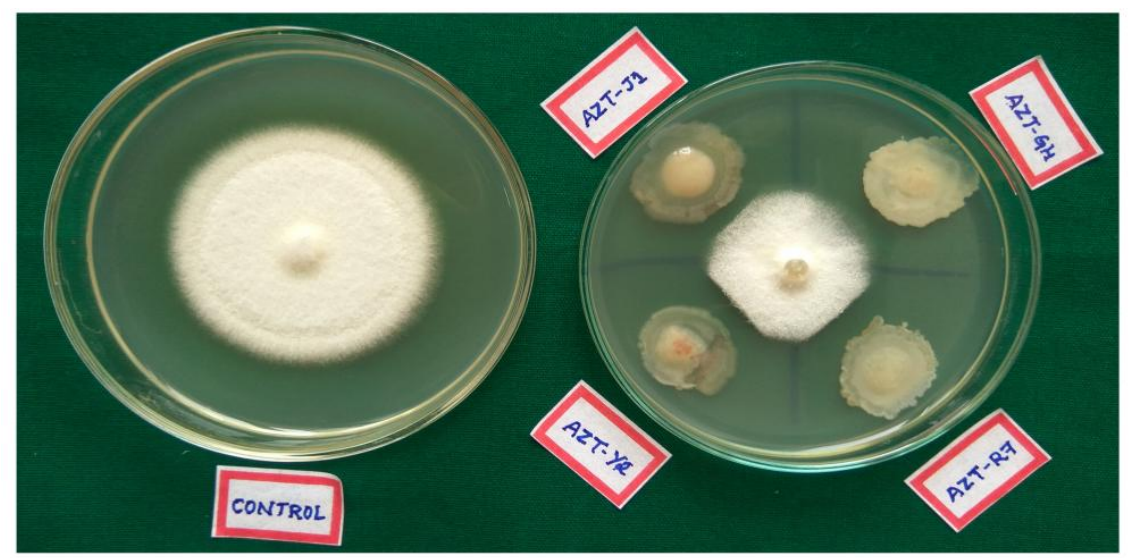

Plate.4 Change in the color of CAS agar medium from blue to reddish yellow indicating the production of siderophore by AZT- $\mathrm{R}_{7}$

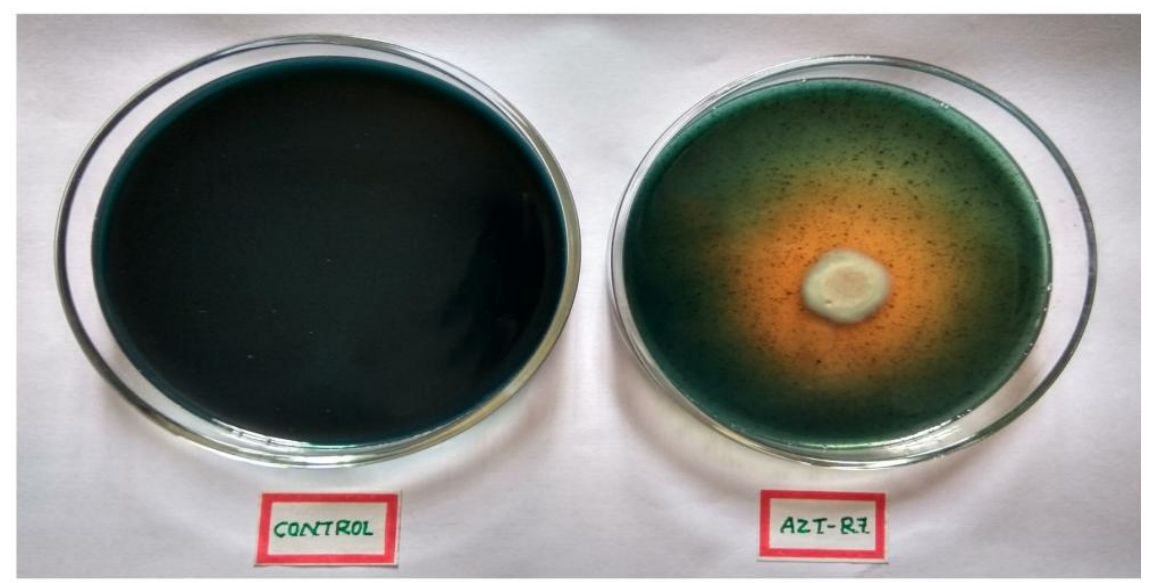


Plate.5 Development of red color in Ashby's N free medium supplemented with tryptophan indicating positive for the IAA production test

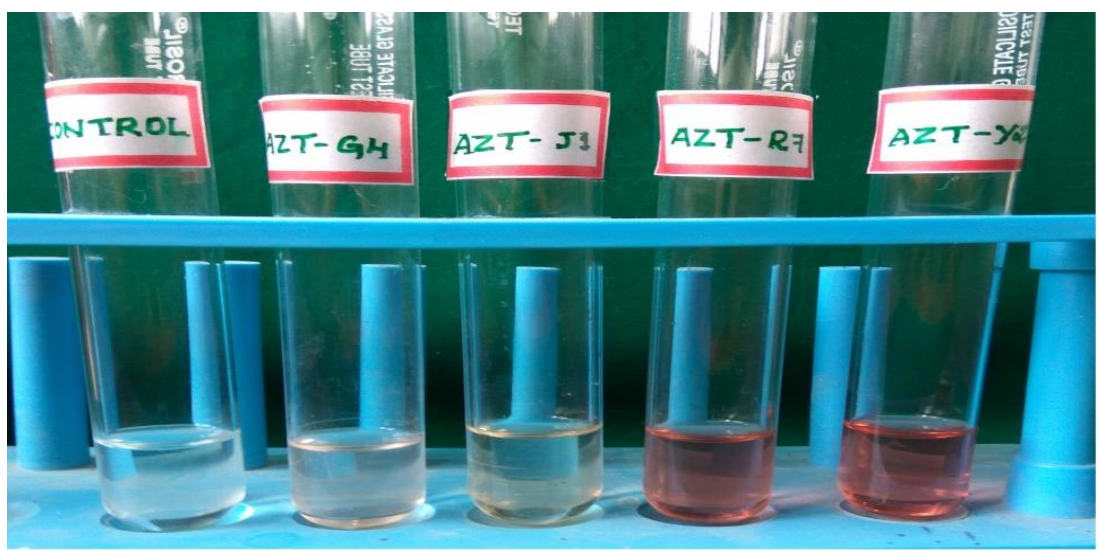

Plate.6 Production of $\mathrm{HCN}$ by AZT-R $\mathrm{R}_{7}$ isolate Plate.7 P-solubilization by AZT-G 4 isolate

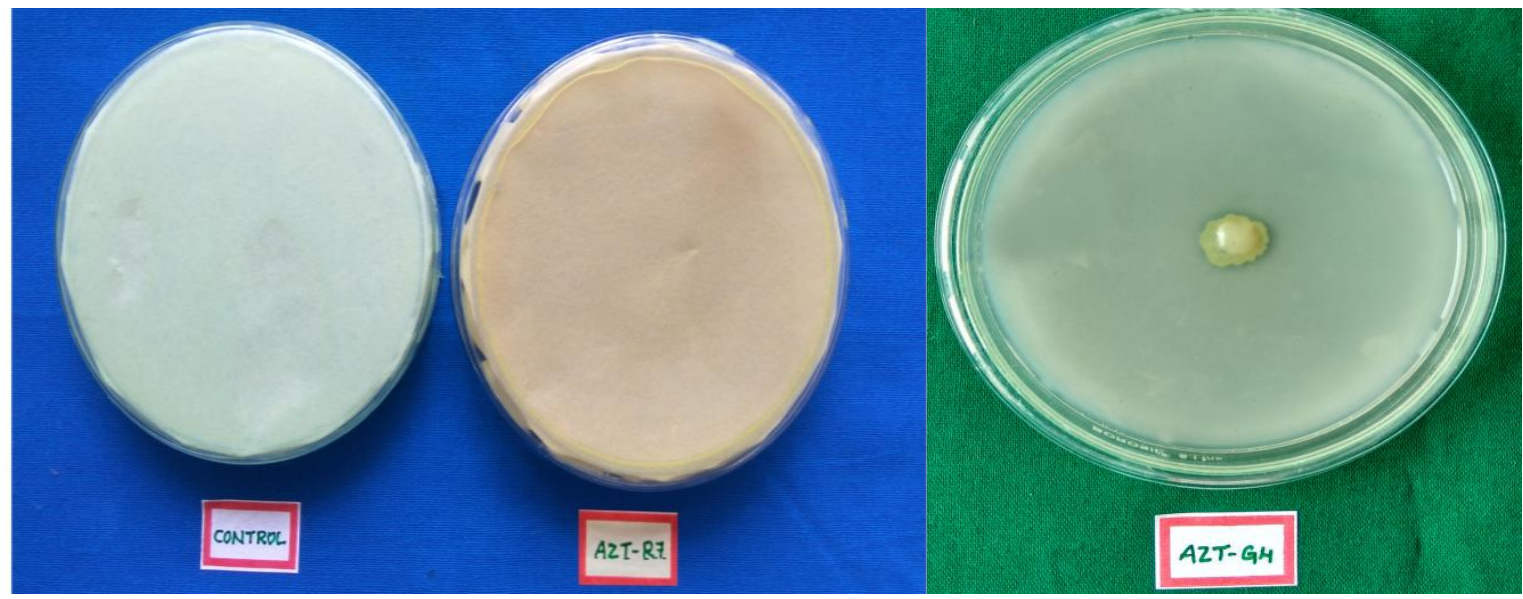

In vitro screening of Azotobacter isolates against Fusarium solani by dual culture technique

Four isolates viz., AZT-R 7 , AZT-G 4 , AZT- $\mathrm{J}_{1}$ and $\mathrm{AZT}-\mathrm{Y}_{2}$ were found highly efficacious in inhibiting the mycelial growth of the $F$. solani. It ranged from 51.47 to 60.25 per cent in dual culture technique. Similarly, Chauhan et al., (2012), reported that isolates of Azotobacter inhibit the mycelial growth of fungal pathogen in dual cultures. Dragana et al., 2015 reported its antifungal activity against Helminthosporium and Macrophomina, which ranged from 10-48 per cent (Table 1 and Plate 3).
Elucidation of biocontrol mechanisms of efficient Azotobacter isolates against $F$. solani

All the isolates fixed $\mathrm{N}_{2}$ in the Waksman no. 77 broth medium. It ranged from 8.27 to $10.33 \mathrm{mg} \mathrm{g}^{-1}$ of mannitol source used after 7 days of incubation. The results of this findings correlates with the findings of Akhter et al., (2012), Murumkar et al., (2012), Jnawali et al., (2015) (Table 2). In this study efficient Azotobacter isolates were stab inoculated in to the SIM agar tubes and incubated for $48 \mathrm{~h}$ at $28^{\circ} \mathrm{C}$ and observed for the development of black colour along the line of stab due to the reaction of ferrous ion 
with $\mathrm{H}_{2} \mathrm{~S}$ to give ferrous sulphide, were considered as positive for the test and those who do not developed black colour were scored negative. The two isolates, AZT- $\mathrm{G}_{4}$ and AZT- $\mathrm{J}_{1}$ showed positive results, whereas AZT-R ${ }_{7}$ and AZT-Y ${ }_{2}$ showed negative results (Abdel-Hamid et al., 2010; Kasa et al., 2016). All the efficient Azotobacter isolates viz., AZT-R ${ }_{7}$, AZT-G 4 , AZT-J ${ }_{1}$ and AZT-Y A he $_{2}$ produced $\mathrm{HCN}$, but the intensity in changing the color varied from isolate to isolate. $\mathrm{HCN}$ is a broad spectrum antimicrobial compound involved in the suppression of root diseases (Plate 4-6). The cyanide ion is exhaled as $\mathrm{HCN}$ and metabolized to lesser degree into other compounds. It inhibits the electron transport and the energy supply to cell is disrupted leading to death of the cell. HCN synthesis by the Azotobacter isolates acts as the inducing agent of systemic resistance in chilli and also it has got potentiality to not get repressed by the fusaric acid produced by the Fusarium. On the Chrome Azurol S (CAS) blue media all the four isolates have produced the orange colonies, indicating the activity of iron chelaters, the colonial zone varied with the isolate. Further they are quantified using CAS shuttle assay of Payne (1994), it ranged from 82.83 per cent $\left(A Z T-R_{7}\right)$ to 77.44 per cent $\left(A Z T-G_{4}\right)$. This character of iron chelation is an important factor for the Azotobacter isolates, as it deprives the pathogen from the available iron in the surrounding (Muthuselvan et al., 2013). All the isolates produced IAA. It ranged from 60.87 to $100.75 \mu \mathrm{g} 50 \mathrm{ml}^{-1}$. The results obtained are in agreement with the findings of several reports (Vikram Patil, 2011; Sivasankari et al., 2016 and Monokoane et al., 2016). The two isolates $A Z T-R_{7}$ and AZT- $\mathrm{G}_{4}$ were positive for the $\mathrm{H}_{2} \mathrm{~S}$ test and only one isolate AZT-G $\mathrm{G}_{4}$ solubilized TCP in the Pikovskaya's medium. Tejera et al., (2005) reported similar kind of biochemical characters of Azotobacter isolates which were isolated from sugarcane rhizospheric soils.

\section{References}

Abdel-Hamid., Marwa, S., Elbaz, A. F., Ragab, A. A., Hamza, H. A. and El Halafawy, K. A., 2010, Identification and characterization of Azotobacter chroococcum isolated from some Egyptian soils. J. Agric. Chem. Biotechnol., 1(2): 93-104.

Akhter, Md. S., Hossain, S. J., Hossain, A. S. K. and Datta, R. K., 2012, Isolation and characterization of salinity tolerant. Azotobacter sp. Gr. J. Biol. Sci., 2(3): 43-51.

Barnett, H. L. and Hunter, B. B., 1972, Illustrated Genera of Imperfect Fungi. Basic Microbiol., 48: 455-463.

Chauhan, S., Wadhwa, K., Vasudeva, M. and Narula, N., 2012, Potential of Azotobacter spp. as biocontrol agents against Rhizoctonia solani and Fusarium oxysporum in cotton (Gossypium hirsutum), guar (Cyamopsis tetragonoloba) and tomato (Lycopersicum esculentum). Arch. Agric. Soil. Sci., 58(12): 1365-1385.

Dennis, C. and Webster, J., 1971, Antagonistic properties of species groups of Trichoderma in production of non- volatile antibiotics. Trans. $\mathrm{Br}$. Mycol. Soc., 57: 25-39.

Dragana, D, B., Jelena, B. M., Tintor, B. B., Tancic, S. L. and Nastasic, A., 2015, Screening of Azotobacter isolates for PGP properties and antifungal activity. J. Nat. Sci., 129: 65-72.

Gibbs, B. M. and Shapton, D. A., 1968, Identification methods for microbiologists. SfAM., No.2 pp.xi+212 pp.

Humpries, E. C., 1956, Mineral components and ash analysis, In: Modern Methods of Plant Analysis, Ed. Peach, K. and Tracey, M.V., Springer, Verlag, Berlin, pp.468-502. 
Jnawali, A. D., Oljha, R. B. and Marahatta, S., 2015, Role of Azotobacter in soil fertility and sustainability. Adv. Plant. Agric. Res., 2(6): 1-5.

Kasa, P., Modugapalem, H. and Battini, K., 2016, Isolation, screening and molecular characterization of plant growth promoting rhizobacteria isolates of Azotobacter and Trichoderma and their beneficial activities. J. Nat. Sci. Biol. Med., 6(2): 360-363.

Lorck, H., 1948, Production of hydrocyanic acid by bacteria. Physiologia Plantarum., 1: 142-146.

Mali, G. V., Patil, R. C. and Bodhankar, M. G., 2011, Antifungal and phytohormone production potential of Azotobacter chroococcum isolates from groundnut (Arachis hypogea L.) rhizosphere and their effect on nodulation and dry mass, along with native rhizobia in pot culture experiment. Res. J. Chem. Environ., 15(2): 172-179.

Monokoane, P. C., Bekele, M. S. and Haiying, L., 2016, Isolation, molecular characterization and growth promoting activity of free living diazotrophs screened from soils of Lesotho. Acad. J. Agric. Res., 4(2): 045-052.
Murumkar, D. R., Borkar, S. G. and Chimote, V. P., 2012, Diversity of cell morphology, nitrogenase activity and DNA profile of Azotobacter isolates from soils of Maharastra. Bioinfolet., 9(4): 851-858.

Muthuselvan, I. and Balagurunathan, R., 2013, Siderophore production from Azotobacter sp. and its application as biocontrol agent. Int. J. Cur. Res. Rev., 5(11): 23-35.

Payne, S. M., 1994, Detection, isolation and characterization of siderophores. Methods Enzymol., 235:329.

Rangaswami, G. and Mahadevan, A., 1999, Diseases of crop plants in India 4th Ed., Prentice hall of India Pvt. Ltd., New Delhi, pp.65-66.

Sivasankari, B. and Anandhraj, M., 2016, Indole acetic acid production and enhanced plant growth promotion of Vigna unquiculata (L.) walp by Azotobacter sp. Int. J. Adv. Res., 4(5): 1445-1450.

Vikram Patil., 2011, Production of indole acetic acid by Azotobacter sp. Rec. Res. Sci. Technol., 3(12): 14-16.

Wu, F. J., Moreno, J. and Vela, G. R., 2006, Growth of Azotobacter vinelandii. Appl. Environ. Microbiol., 58: 78-82.

\section{How to cite this article:}

Swapna, K. Tamil Vendan, Mahadevaswamy, D.S. Aswathanarayana and Gundappagol, R.C. 2018. Biocontrol Mechanisms of Efficient Azotobacter Isolates against Fusarium solani Causing Fusarium wilt of Chilli (Capsicum annum L.) under in vitro Conditions. Int.J.Curr.Microbiol.App.Sci. 7(09): 2696-2702. doi: https://doi.org/10.20546/ijcmas.2018.709.335 